\title{
○特集 情報素子としての生体膜およびその模倣技術の開発
}

\section{神経ーグリア細胞系におけるカルシウム波と カルシウム振動：その測定と発生機構 佐野雅己・中村秀樹・吉田 篤}

東京大学大学院理学系研究科 $=113-0033$ 東京都文京区本郷 $7-3-1$

\section{Observation of Calcium Activities in Newron-Glia Co-cultured System : Seacrhing for underling mechanism}

\author{
Masaki Sano, Hideki Nakamura and Atsushi Yoshida \\ Department of Physics, Graduate School of Science, University of Tokyo, \\ Hongo 7-3-1, Bunkyo-ku, Tokyo 113-0033, Japan
}

Cultured neural network is a useful tool for the understanding of fundamental functions and structure of nervous system. In this biological neural network, nerve cells mutually communicate by electrical or chemical interactions, and exhibit collective dynamics of activities such as synchronous bursting or calcium wave propagation. Photostimulation by using caged-glutamate were performed to elucidate the mechanism of $\mathrm{Ca}$ wave propagations through the measurement of the speed of $\mathrm{Ca}$ wave, rising time of $\mathrm{Ca}$ increase, and range of propagation, etc. To analyze the activity and dynamical connectivity of the cultured network, we quantified spontaneous collective dynamics of the network by lowering magnesium concentration in extracellular solution. From the visualization of network structure, cell type discrimination by MAP2 monochronal antibody, and measurement of dynamical activity by $\left[\mathrm{Ca}^{2+}\right]$ sensitive dye, we quantitatively elucidated that collectivity of the network activities were increased due to the development of long-range interaction between neurons.

Key words: neuron / glial cells / astrocyte / calcium wave / calcium oscillation / model

\section{1 はじめに}

脳の情報処理の基本単位である神経細胞に関し ては，膨大な電気生理学データが積み重ねられて きたが，近年，ゲノム解析の急速な進展や細胞内 信号伝達系の解析が進むにつれ，神経系において も化学物質等による電位以外の信号伝達に関する 研究が今後急速に進展することが予想されてい る。また，神経細胞だけでなく，グリア細胞の機 能に対する関心も高まっている，従来，グリア細
胞は神経系の栄養補給など補助的な役割を担って いると考えられてきたが，両者が化学物質を仲介 として相互作用していることが明らかになり，現 在では積極的に情報処理にかかわっている可能性 も指摘されており ${ }^{1,2)}$, 神経一グリア系の研究は 今後いっそう重要性をましていくものと考えられ る。私たちは，神経系に見られる興奮や振動現象 の非線形・非平衡の側面と，そのようなアクティ ブな素子が多数集まったシステムが集団活動によ り機能を持つことに興味を持ち, 細胞の集団活動 


\section{$\underline{\text { Primary dissociated culture of }}$ $\underline{\text { rat cortex }}$}

- E18 Rat Cortex,

- Polyethylenimine coating, $10^{6}$ cells per well

- DMEM, $37^{\circ} \mathrm{C}, \mathrm{CO}_{2} 5 \%$
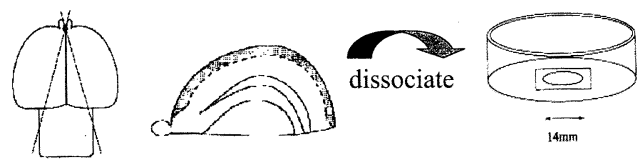

cf. Kuroda, Kobayashi, J. Neurophysiology, 70, 1606 (1993)

Maeda, Jinbo, J. Neuroscience, 15, 6834 (1995)

Fig. 1 Dissociated Cell Culture of Neuron and Glia

を記録し解析することから機能の理解に迫ろうと 考え数年前に研究を開始した. 現在, 私たちは神 経一グリア集団に見られる極めて動的な信号伝達 であるカルシウム波とカルシウム振動”に着目し て，その動態と発生機構や機能的役割などを解明 すべく様々の実験を行っている，興奮波の伝播と 同期振動は, 非線形・非平衡系の理論的枠組みで は比較的よく扱われる現象であるが, 細胞内・細 胞間のカルシウム伝播に関する最近の実験結果に より，それが通常の興奮波と異なった性質を持ち， 生理学的にも意味を持つものであることが分かっ てきた。以下にカルシウム波に関する研究の現状 と私たちが得た新しい知見について述べることに する.

\section{2. 実験方法および結果}

\section{1 実験系}

神経一グリアの培養ネットワークを構成するた め、ラット胎児（17１8日）の大脳皮質から取り出 した細胞を解離し，ガラス基盤上に分散培養し4), 培養日数の経過に伴って形成されたネットワーク についてその構造と細胞内 $\mathrm{Ca}^{2+}$ 濃度の可視化と集 団活動の定量化などを行った（Fig.1）。細胞内 $\mathrm{Ca}^{2+}$ 濃度の計測には，レーザー共焦点顕微鏡と蛍 光顕微鏡を用いた。また $\mathrm{Ca}^{2+}$ 濃度の観測後には細 胞を固定し，抗体染色を行うことにより，神経細 胞とグリア細胞を特定し $\mathrm{Ca}^{2+}+$ 活動における両者の
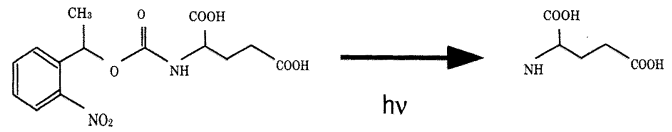

Caged Glutamic Acid

Glutamic Acid

Fig. 2 Photostimulation by a flush pulse laser photolysis of caged compound

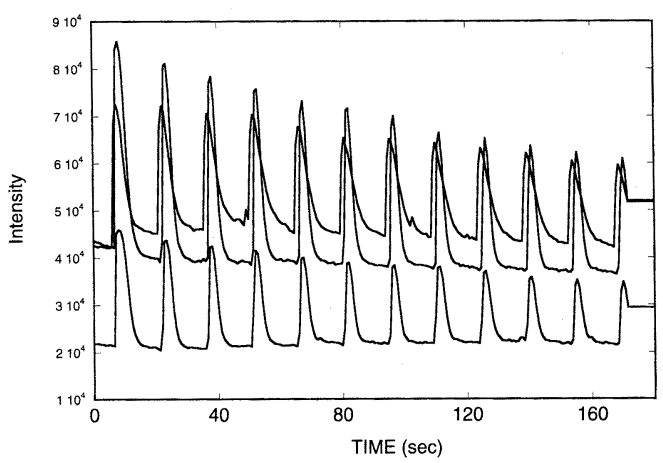

Fig. 3 Stimulation by glutamate using laser photolysis and $\mathrm{Ca}^{2+}$ response of the cell

動態の違いを解析した.

\section{2 外部刺激によるカルシウム波の生成}

\section{(a)レーザーフォトリシスによる局所刺激}

神経グリア系におけるカルシウム波などの応答 を調べるには，ピペットによる薬物刺激などの方 法が考えられるが，ここではレーザーフォトリシ スによる局所刺激の方法を取る5),6)。レーザー照 射とcaged化合物を用いたこの方法では，ピペッ トによる刺激に比べて, 局所的でかつ正確な夕イ ミングで神経伝達物質を与えることができるとい う利点がある。この方法では, 神経のデンドライ トの近傍にUVレーザーで $5 \mathrm{~ns}$ の時間幅のパルス を照射するごとにより，あらかじめ溶液に溶かし たcaged-Glutamateを解離させ（Fig.2），本来は前 シナプスから放出されて後シナプスに伝えられる 神経伝達物質であるグルタミン酸を, 特定の細胞 のねらった部位に局所的に与えることが可能であ る.この際の刺激スポットの大きさは, 対物レン ズゃレーザーパワーを変えることにより $1 \mu \mathrm{m}$ から $20 \mu \mathrm{m}$ の範囲で調整可能である。また与えるグル タミン酸の濃度は, あらかじめ溶かしておく 


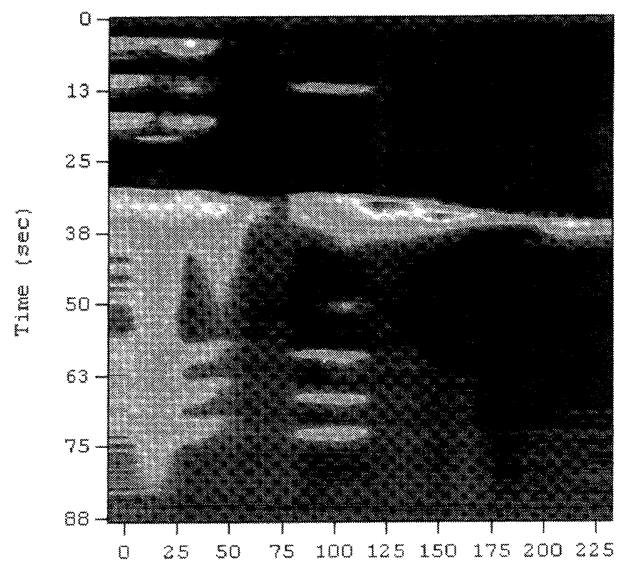

Fig. $4 \mathrm{Ca}^{2+}$ wave propagation by stimulation (Horizontal axis: distance of propagation $(\mu \mathrm{m})$, Vertical axis: elapsed time (sec))

caged-Glutameteの濃度とレーザー光のパワー，照 射するパルスの回数などによって制御可能である ことなど様々の利点を持っている．実際の照射ス ポットサイズや形状は, caged-Fluoresceinなどを 用いて,レーザー解離により生じた蛍光を観測し， スポットの形状やプロファイルを計測することで 一定の校正を行うことができる。このように細胞 に目的の情報伝達物質を与え, 細胞内イオンの標 識用としてはカルシウム感受性蛍光色素などを使 うことにより，刺激による細胞の応答を光学的に 測定することができる.

\section{3 測定結果}

神経グリア培養系において, caged-Glutamateを レーザーフォトリシスにより解離させ，一つの細 胞の近傍にグルタミン酸を与えると，刺激を与え られた細胞のカルシウム濃度は一定の時間遅れの 後に上昇し, その後, 隣接した細胞のカルシウム 濃度が上昇し，さらに隣接した細胞へとカルシウ ムの波が伝播していく様子が観察される。この場 合の，個々の細胞の応答と細胞間のカルシウム波 伝播の結果をFig.3とFig.4に示す。これらの応答 から測定可能なことはいくつかある.第一に単一 細胞への刺激に対するカルシウム応答の立ち上が りを解析することにより， $\mathrm{Ca}^{2+}$ の増幅機構が分か る. Fig.5に単一細胞のGlutamate刺激に対する応

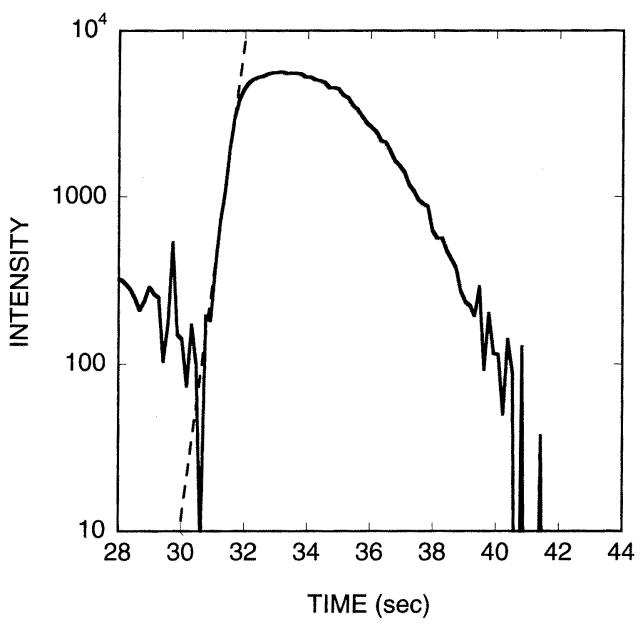

Fig.5 $\mathrm{Ca}^{2+}$ response of single cell

答を片対数グラフで示す. 1 桁以上の範囲におい て相対濃度が刺激とともに指数関数的に上昇して いることがわかる。このことから，振幅の小さい 線形領域においては，指数関数的にCa ${ }^{2+}$ 濃度が上 昇する自己増殖的な反応過程があることが分か る.また，この時の指数関数の特徵的時間から反

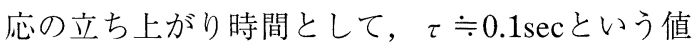
が得られた。減衰過程に関しては，振幅が小さい 範囲においてのみ指数関数的な減衰を見せている が，上昇に比べやや複雑な応答を示していること が言える。次に細胞間のカルシウム波伝播に関し てこの実験から得られる知見について述べる。ま ず，カルシウム波が伝播する距離は有限であり， その距離は与えられた伝達物質の量に依存するこ とが明らかになった. $10 \mu \mathrm{M}$ の caged-Glutamate濃 度の場合には 1 度の刺激により，4〜5個先の細 胞までしか伝播しないが，レーザーパルスを連続 して照射し，解離する量を増やしてやると10個以 上離れた細胞にまでカルシウム波が伝播する．各 細胞の応答が最大值の半分の振幅に達する時間か ら, 細胞間の伝播の時間遅れを測定し，伝播速度 を見積もると $4 \sim 5$ 個までの範囲では約 $15 \mu$ $\mathrm{m} / \mathrm{sec}$ の速度であった. 非線形波動に関する知見 から，反応の立ち上がり時間 $\tau$ と波の伝播時間 $v$ との間には，次のような関係があることが知られ ている。 


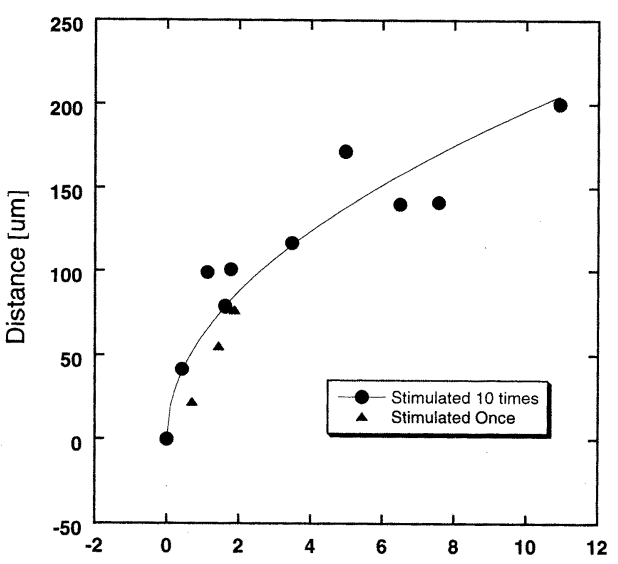

Fig. $6 \mathrm{Ca}^{2+}$ wave propagation curve (Horizontal axis: elapsed time (sec), Vertical axis: distance of propagation $(\mu \mathrm{m})$ )

$$
v=\sqrt{\frac{D}{\tau}}
$$

ただし，ここでDは興奮波の興奮性物質の拡散定 数である.この関係に上で得られた值を代入する ことにより，D〜220 $\mu \mathrm{m}^{2} / \mathrm{sec}$ という值が得られる。 カルシウム波の興奮を引き起こす物質として，イ ノシトール 3 燐酸 $\left(\mathrm{IP}_{3}\right)$ や $\mathrm{Ca}^{2+}$ 自身が候補として 挙げられるが,それぞれの細胞内での拡散定数は, 約 $280 \mu \mathrm{m}^{2} / \mathrm{sec}$ と $13 \mu \mathrm{m}^{2} / \mathrm{sec}$ 程度であることが知ら れている7). (IP の拡散定数が小さいのは，カルシウムに結合する 蛋白やキレート物質などが細胞内に多く存在する ためであると考えられている。）上で得られた拡 散定数との比較から，カルシウム波の伝播は, $\mathrm{Ca}^{2+}$ によって引き起こされるのではなく $\mathrm{IP}_{3}$ の拡散 によって引き起こされていると考えることができ る. $\mathrm{IP}_{3}$ は, 細胞間のギャップジャンクションを 通過して隣接した細胞に拡散することが知られて

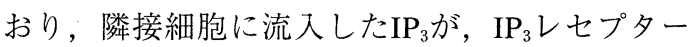
に結合し小胞体からの $\mathrm{Ca}^{2+}$ の放出を促すものと考 えられる，このことは， $\mathrm{Ca}^{2+}$ 波の伝播距離が有限 であるという事実によっても裏づけられる。 $\mathrm{IP}_{3}$ は，グルタミン酸を受けたレセプターの近傍で生 成されるので, 隣接した細胞でのIP 3 濃度の上昇 は他の細胞からの $\mathrm{IP}_{3}$ の拡散だけによっている. そのため $\mathrm{IP}_{3}$ が細胞間を拡散するにつれ濃度が下

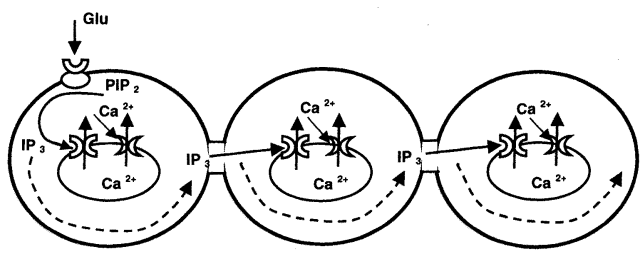

Fig. 7 Mechanism of $\mathrm{Ca}^{2+}$ wave propagation

がっていき， $\mathrm{Ca}^{2+}$ 放出に必要な閾值を下回ると $\mathrm{Ca}^{2+}$ 波の伝播は停止する。この時，伝播速度は刺 激部位から遠ざかるほど遅くなり，伝播距離は時 間の平方根に比例する振る舞いをみせる（Fig.6）. このことも $\mathrm{IP}_{3}$ の拡散現象として説明できる。ま た，刺激物質の量が多いほど伝播距離が延びる事 実は，放出されるIP ${ }_{3}$ の量が多い場合は，遠くま でIP ${ }_{3}$ が拡散しても間值レベルを超える範囲が広 がることで説明可能である。

\section{4 カルシウム波の発生機構}

以上述べた実験事実を反映して， $\mathrm{Ca}^{2+}$ 波のモデ ルを構成することができる，考慮すべきは，外部 刺激によって生成される $\mathrm{IP}_{3}$ の拡散, $\mathrm{IP}_{3}$ が $\mathrm{IP}_{3}$ 受容 体に結合することにより小胞体より放出される $\mathrm{Ca}^{2+}\left(\mathrm{IP}_{3}\right.$ Indecued Calcium Release : IICR) と $\mathrm{Ca}^{2+}$ が小胞体の受容体に結合することによって放出さ れる $\mathrm{Ca}^{2+}$ (Calcium Induced Calcium Release : CICR) である8)（Fig.7）。 $\mathrm{Ca}^{2+}$ 波に関してはこれまで， $\mathrm{IP}_{3}$ だけによるC $\mathrm{Ca}^{2+}$ 放出を考えCICRを考えないモ デルが提案されているが9)，このモデルでは実験 で得られた細胞の $\mathrm{Ca}^{2+}$ 応答のデータと一致するこ とはできない，この受動的なモデルでは， $\mathrm{IP}_{3} に$ よって引き起こされた $\mathrm{Ca}^{2+}$ 濃度の上昇が，拡散に より $\mathrm{IP}_{3}$ 濃度が減少するまでの期間続くため, 最 初に刺激された細胞が最後まで最も高い $\mathrm{Ca}^{2+}$ 濃度 を保つことになってしまうからである。しかし， 実験ではどの細胞もほぼ一定の応答波形を示し, $\mathrm{Ca}^{2+}$ 濃度の高い細胞は刺激を受けた細胞から遠く の細胞へと順々に伝わっていくことが分かってい る。この実験事実を説明するには，受動的モデル では不充分でCICRを取り入れながら， $\mathrm{IP}_{3}$ の拡散 が $\mathrm{Ca}^{2+}$ 拡散より大きいことを取り入れたモデル が必要になる。そこで我々は，IICRとCICRを取 
(a)

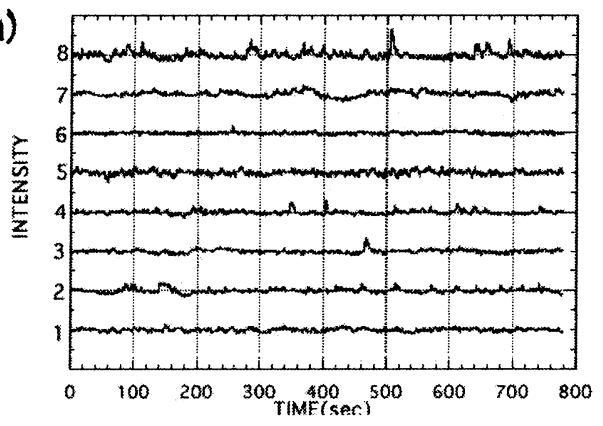

(b)

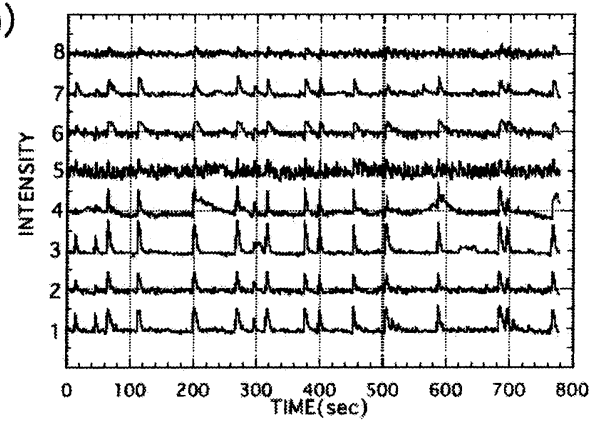

(c)

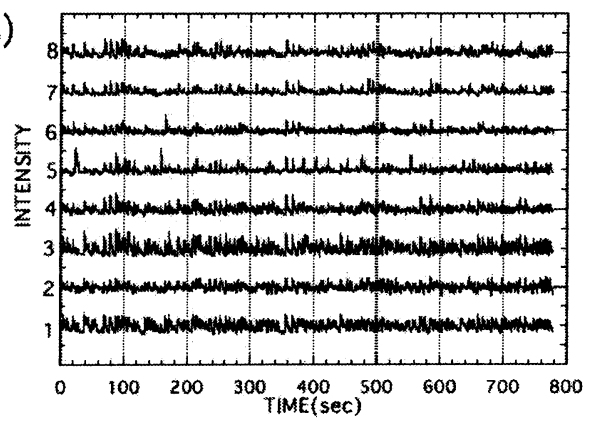

Fig. 8 Time series of spontaneous Ca activities. (a) day 4 , (b) day 8 , (c) day 14

り入れた以下のような $\mathrm{Ca}^{2+}$ 波のモデルを考え，シ ミュレーションを行っている.

$\frac{\delta P}{\delta t}=\alpha-\frac{V_{p} k_{p} P}{k_{p}+P}+D_{p} \nabla^{2} P$

$\frac{\delta c}{\delta t}=k P+J_{f u x}-J_{p u m p}-\beta c+D_{c} \nabla^{2} c+\beta_{I} c_{I}$

$\frac{\delta c_{l}}{\delta t}=J_{p u m p}-J_{f u x}-\beta_{I} c_{I}$

$J_{f u x}=k_{f u x} \frac{c^{n}}{k_{A}^{n}+c^{n}} \frac{c_{I}^{r}}{k_{I}^{r}+c_{I}^{r}}$

$J_{\text {pump }}=\frac{\gamma c^{m}}{k_{r}^{m}+c^{m}}$
ここで, $P$ は $\mathrm{IP}_{3}$ の濃度, $c$ は細胞質内の $\mathrm{Ca}^{2+}$ 濃度, $c_{I}$ は小胞体内の $\mathrm{Ca}^{2+}$ 濃度, $J f u x$ は小胞体内から CICRによって放出される $\mathrm{Ca}^{2+}$ の量, Jpump は細胞質 内から小胞体内に輸送される $\mathrm{Ca}^{2+}$ の量を表してい る.

\section{3. 自発的カルシウム振動の発生}

\section{1 同期発火現象の定量化}

培養細胞系は, 通常の培養条件や観測用バッフ ア溶液で観測を行うと，カルシウム活動を見る限 りでは自発的な活動はまれにしか起こらない。そ のため $\mathrm{Ca}^{2+}$ 波の応答を見ようとすればGlutamate刺 激や電気刺激を行う必要があった。まれに一部の 細胞のカルシウム濃度が時間振動することもある が，それが細胞全体に広がることはない。（電気 活動を測定した報告によると，自発的なアクショ ンポテンシャルは, 頻度は高くないが発生してい る.）しかし，測定用の溶液を $\mathrm{Mg}^{2+}$ 含まないも のに変えてやると, 細胞系全体に強い同期発火の バーストが起こり, 同時にカルシウム濃度の振動 が観測される。この過程における時系列の観測結 果をFig.8に示す。計測は，視野内の全ての細胞 (約500個）についてその時系列を約20分間にわた り同時記録した。これは, もともと一定程度存在 する自発的な電気活動によりシナプスから神経伝 達物質が放出され, シナプス後細胞のデンドライ トの電位が上昇するとともに, $\mathrm{Mg}^{2+}$ フリーにし たことにより，神経細胞のNMDAレセプターの $\mathrm{Mg}$ ブロックが外れやすくなり, $\mathrm{Ca}^{2+}$ イオンが神 経細胞内に流入し濃度が上昇し, 遅れて $\mathrm{Ca}^{2+}$ ポン プが㗢くことにより振動が起こっているものと予 想される。また，この時に興奮した細胞のシナプ スからはグルタミン酸が放出されるため, 周辺の グリア細胞でも $\mathrm{Ca}^{2+}$ 濃度の上昇が引き起こされ細 胞系全体に同期的振動が広がるものと考えられ る.この同期発火状態では約200ミクロン離れた 視野内の細胞間で時間の遅れは殆ど見られない (30msec以下) ことから, $\mathrm{IP}_{3} や \mathrm{Ca}^{2+}$ の興奮波の伝 播速度を越えており，電気的興奮波による同期振 動現象であると考えられる。我々はこの状態にあ 
Development of Neuron-Neuron Correlations

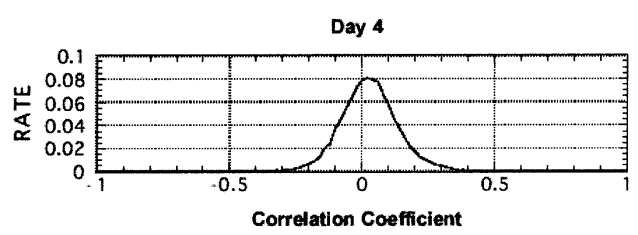

Day 8

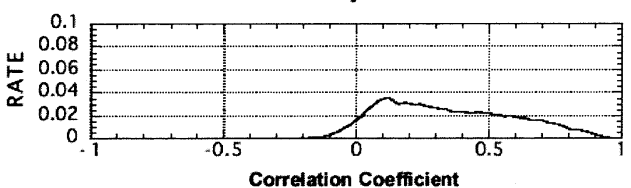

Day 14

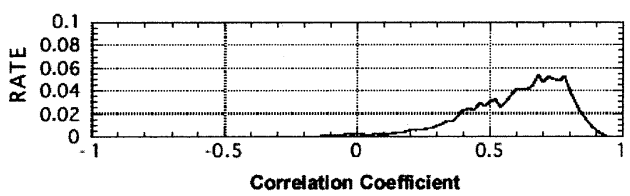

Fig. 9 Evolution of a distribution function of neuron-neuron correlation coefficient, (a) day 4, (b) day 8 , (c) day 14

る全ての細胞の時系列を計測し，相互相関関数を 測り解析した。時系列解析を行った結果，自発発 火状態の $\mathrm{Ca}^{2+}$ 活動パターンには，上で述べた同期 発火の他にも，殆ど同期が見られず各細胞がほぼ ランダムに発火するランダム発火や，まれには伝 播型の $\mathrm{Ca}^{2+}$ 波も観測されることを確認した。この うち同期発火が見られた場合について, 神経細胞 とグリア細胞がどのように相互作用しているのか を確かめるため, 測定終了後直ちに抗体染色を行 い, 神経とグリア細胞を并別し, 細胞の種類を分 けて相互相関を計算した。抗体染色には，神経に 特異的に発現するMAP2の抗体を用い, さらにそ れに結合する2次抗体で蛍光観察を行った. 神 経一神経間の相関係数, 神経ーグリア間の相関係 数，グリアーグリア間の相関係数を全ての細胞の 組み合わせについて計算し, それぞれの相関係数 のヒストグラムを得て，培養からの日数とともに 分布関数がどう変化するかを調べたのがFig.9, Fig.10，Fig.11である。最も相関の高いものは,

\section{Development of Neuron-Glia Correlations}
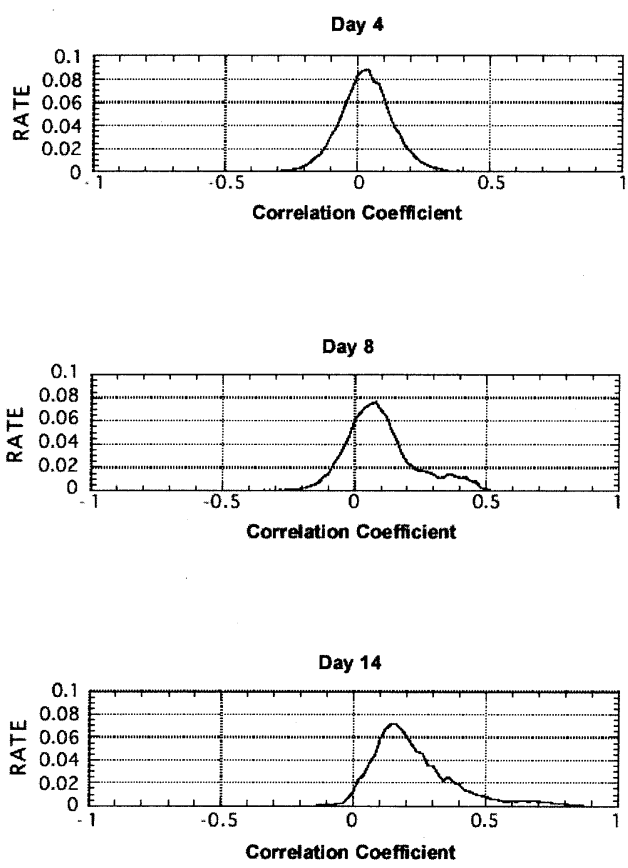

Fig.10 Evolution of a distribution function of neuron-glia correlation coefficient, (a) day 4 , (b) day 8 , (c) day 14

神経一神経間の相関であり，培養 4 日目では殆ど 相関がなかったものが8日目では相関が上昇し， 14日目では殆どの細胞間で強い相関が見られる。 これに対して神経とグリアの $\mathrm{Ca}^{2+}$ 活動の相関は弱 いが，14日目では相関係数の平均值が 0 から正に シフトしており，両者が情報的に相互作用して同 期発火が起こっていることを示す実験結果が得ら れた.グリアーグリア間の相関もほほ同様であっ た。また同期活動の解析には新しい試みとして改 良された主成分分析を用いて，全細胞数の中で何 個の細胞が同期しているかを定量化した，相関係 数の行列の固有值と固有ベクトルが，互いに直交 する相関クラスターの分解に関係していることを 利用して, 相関の強いクラスターに含まれる細胞 を抽出した，その結果，主成分分析の第一固有心 クトルに対応する同期クラスターに含まれる細胞 が日数とともに増大し，培養 1 週間から 2 週間で は，ほぼ半数の細胞が第一主成分で説明される同 期発火を起こすようになり，全体の同期化が強ま 


\section{Development of Glia-Glia Correlations}
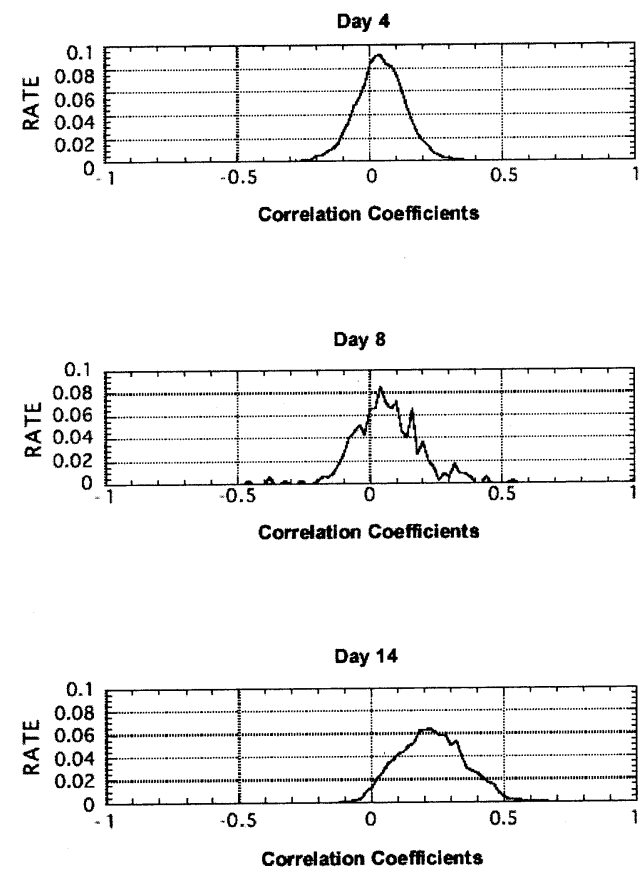

Fig.11 Evolution of a distribution function of glia-glia correlation coefficient, (a) day 4, (b) day 8, (c) day 14

っていく様子が明確になった。

\section{2 ネットワーク構造の定量化}

培養日数とともに形成されるネットワーク構造 をMAP2の抗体染色により可視化し, 細胞同士が 互いに接続していると見られるクラスターの大き さを定量化した。培養 5 日目と14日目におけるネ ットワークの構造をそれぞれFig.12, Fig.13に示 す，定量化の方法には，Gyration 半径の測定を用 いた。その結果, 接続の広がりを表すGyration 半 径が日数とともに指数関数的に成長する様子が明 らかになった (Fig.14)。また, Gyration 半径と同 期発火には強い相関があることが確認された。実 際に培養日数と無関係にプロットした全細胞ペア の相関係数の平均值とGyration 半径の関係は強い 正の相関を持っていることは当然予想した通りで あった。しかし，同じ培養日数でもサンプルによ るばらつきのためネットワークの発達の仕方に違

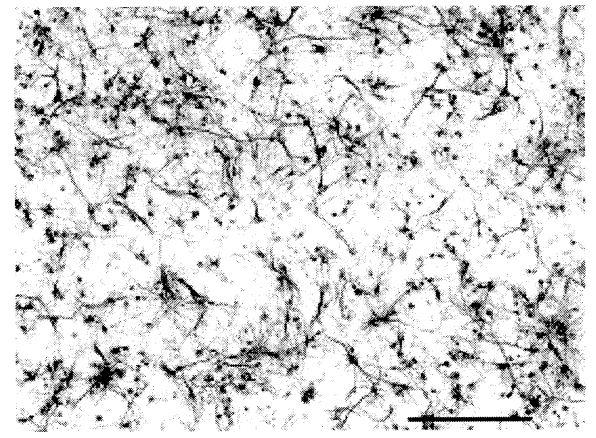

Fig.12 Network structure of the culture on day 5 (MAP2 monochronal staining)

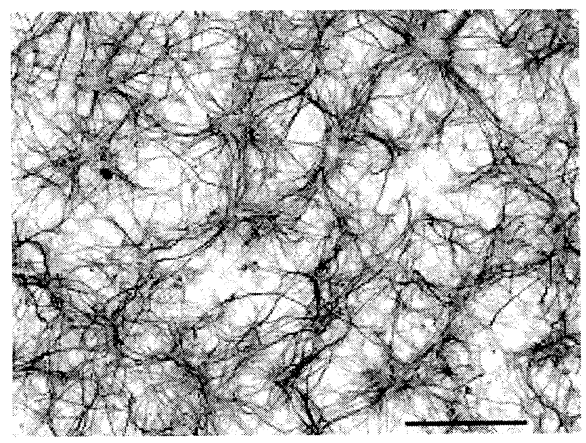

Fig.13 Network structure of the culture on day 11 (MAP2 monochronal staining)

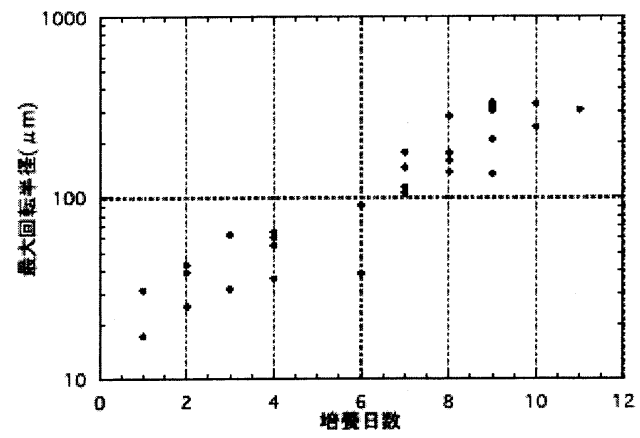

Fig.14 Gyration radius of the maximum cluster in the network vs. elapsed days after dissection.

いがある場合があり，同じ日数でも Gyration半径 はかなり異なってくる。このようなデータに対し ても同じ培養日数のサンプルでGyration 半径と平 均相関係数をプロットするといっそう分散が小さ 
く強い正の相関が見られた。このことは, 発達し たデンドライト構造により互いにシナプス結合を 形成したネットワークの広がりが同期的なCa振 動にとって不可欠であることを示していると考え る.

\section{4. カルシウム波と振動の生物学的意義}

脳細胞の半分以上はグリア細胞が占めている が，その機能は最近まで神経細胞の補助的なもの と考えられてきた。しかし，ここにも述べたよう に最近の研究で, 神経一グリアの複合系として脳 は, ダイナミックな活動を行っていることが明ら かになってきた．脳の中で通常存在するのは大型 グリア細胞（マクログリア）であり，その中には アストロサイトやオリゴデンドロサイトが含まれ る. 現在では, アストロサイトは脳の種々の機能 に関わっているとされ, ニューロンの発育, シナ プスの形成, 細胞間隙の $\mathrm{K}^{+}$イオン濃度の調節に よるニューロンの興奮性の調節, 脳血液関門の形 成, ニューロンのエネルギー源であるグリコーゲ ンの貯蔵とグルコースの遊離, 脳における免疫機 能などを担っているとされている. 生体内でも存 在する $\mathrm{Ca}^{2+}$ 波は, 神経の興奮とグルタミン酸の放 出によって引き起こされ ${ }^{10), 11)}$, その細胞を含む数 10 ミクロンから数 100 ミクロンの空間領域に広が っていく，この空間領域は局所的ではあるが，細 胞数としてはかなり多くの細胞を含んでいる. $\mathrm{Ca}^{2+}$ 波の伝播により信号を受け取ったグリアは， 発生過程ではニューロンの発育を調節することに よりニューロンの空間分布や接続に影響を与える ことが予想される. $\mathrm{Ca}^{2+}$ 波が伝わった空間領域で のシナプス形成を促進あるいは抑制したり, 細胞 間隙の $\mathrm{K}^{+}$イオン濃度の調節により領域内のニュ ーロンを興奮しやすくするなどのフィードバック
を通じて脳の学習機能に大きな影響を与えている 可能性も十分考えられる. 今後, 電気的測定と光 学的測定によるネットワークのマクロレベルの可 塑性の詳細, さらにその分子機構に関する実験が 進展することにより, 脳の機能形成の新しい姿が 見えてくることが期待される.

\section{謝辞}

本報告は, 日本膜学会第23回年会におけるシン ポジウムの講演に新しいデータも付け加え，書き 改めた記録である。講演の機会を与えていただい た委員の皆様に感謝します。

本研究は, 交流協会の援助により実施されまし た。ここに感謝します.

\section{文献}

1) Parpura V., Basarsky T., Liu F., Jeftinija K., Jeftinija S., and Haydon P G., Nature, 369, 744-747 (1994).

2) Pasti L., Volterra A, Pozzan T , and Carmingnoto G, J. Neurosci., 17, 7817-7830 (1997).

3) Jaffe L F., BioEssays, 21, 657-667 (1999).

4) Muramoto K , Kobayashi K , Nakanisi S , Matsuda Y , and Kuroda Y., Proc. Japan Acad., 64, 319-322 (1988).

5) Callaway E M and Katz L.C, Proc. Nat. Acad. Sci. USA, 90, 7661-7665 (1993).

6) Corrie J E T , DeSantis A, Katayama Y, Khodakhah K, Messenger J B, Ogden D C , Trentham D R, J. Physiology, 465, 1-8 (1993).

7) Albritton N.L., Meyer T , Stryer L., Science, 258, 1812 1815 (1992).

8) Goldbeter A , Dupont G , and Berridge M J , Proc. Nat. Acad. Sci. USA, 87, 1461-1465 (1990).

9) Sneyd J , Wetton C , Charles T.R , and Sanderson M J , Am. J. Physiol., 268, C1537-1545 (1995).

10) Cornell-Bell A H , Finkbeiner S M , Cooper M S , and Smith S J , Science, 247, 470-504 (1997).

11) Cornell-Bell A H, and Finkbeiner S M, Cell Calcium, 12, 185-204 (1991)

（受付 2001年10月27日 掲載決定 10月30日） 